\title{
Allocating Group-Level Payments for Ecosystem Services: Experiences from a REDD+ Pilot in Tanzania
}

\author{
Elizabeth J. Z. Robinson ${ }^{1, *}$, H. Jo Albers ${ }^{2}$, Razack Lokina ${ }^{3}$ and Charles Meshack ${ }^{4}$ \\ 1 School of Agriculture, Policy, and Development, University of Reading, Reading RG6 6AR, UK \\ 2 Haub School of Environment and Natural Resources, Department of Economics and Finance, \\ University of Wyoming, Wyoming, WY 82071, USA; Jo.Albers@uwyo.edu \\ 3 Department of Economics, University of Dar es Salaam, Dar es Salaam, P.O. Box 35045, Tanzania; \\ rlokina@udsm.ac.tz \\ 4 Tanzania Forest Conservation Group, Dar es Salaam, P.O. Box 23410, Tanzania; cmeshack@tfcg.or.tz \\ * Correspondence: e.j.robinson@reading.ac.uk; Tel.: +44-118-378-5039
}

Academic Editor: Thomas J. Straka

Received: 14 September 2016; Accepted: 28 November 2016; Published: 6 December 2016

\begin{abstract}
Payments for ecosystem services (PES) typically reward landowners for managing their land to provide ecosystem services that would not otherwise be provided. REDD+-Reduced Emissions from Deforestation and Forest Degradation - is a form of PES aimed at decreasing carbon emissions from forest conversion and extraction in lower-income countries. A key challenge for REDD+ occurs when it is implemented at a group, rather than an individual landowner, level. Whilst achieving a group-level reduction relies on individuals changing their interaction with the forest, incentives are not aligned explicitly at the individual level. Rather, payments are made to a defined group as a single entity in exchange for verified reduced forest loss, as per a PES scheme. In this paper, we explore how REDD+ has been implemented in one multiple-village pilot in Tanzania with the village defining the group. Our findings suggest that considerable attention has been paid towards monitoring, reporting, verification (MRV), and equity. No explicit mechanism ensures individual compliance with the village-level PES, and few villages allocate funds for explicit enforcement efforts to protect the forest from illegal activities undertaken by individual group members or by outsiders. However, the development of village-level institutions, "social fencing," and a shared future through equal REDD+ payments, factor into decisions that influence the level of compliance at the village level that the program will eventually achieve.
\end{abstract}

Keywords: PES; REDD; REDD+; collective decisions; Tanzania; forests

\section{Introduction}

Globally, deforestation and forest degradation contribute approximately $10 \%-12 \%$ of total $\mathrm{CO}_{2}$ emissions [1,2], whilst Africa's relatively high rate of forest degradation and deforestation accounts for approximately $70 \%$ of the continent's total greenhouse gas (GHG) emissions [3,4]. REDD—Reduced Emissions from Deforestation and Forest Degradation-recognizes both the continuing increase in global $\mathrm{CO}_{2}$ emissions and the role of forests in lower-income countries, by introducing a payment conditional on slowing forest conversion and degradation to reduce the emission of greenhouse gases. Forests have long been a part of climate change discussions through the clean development mechanism (CDM), which focuses on afforestation. REDD, in contrast, with its focus on avoided forest loss, is a relatively new innovation, first featured in the 2005 Montreal COP (conference of the parties). In 2010 at the COP-16, REDD became REDD+ to reflect the incorporation of sustainable forest management, conservation, and enhancement of forest carbon stock. 
Although REDD+ remains in its early stages, and is currently being implemented under a variety of guises, central to REDD+ has been the idea that it is a payment for ecosystem services (PES) where payments are conditional on verified reductions in forest loss relative to some baseline $[5,6]$. A key yet neglected issue for REDD+ is the change in incentives that are created for individual forest-dependent households when a REDD+ scheme is introduced at a group level, as is frequently the case for village-owned or -managed forests, and indeed for many PES schemes, in lower-income countries [7].

To address this characteristic of REDD+ implementation, we consider a REDD+ pilot that the Tanzania Forest Conservation Group (TFCG) and the Tanzanian Community Forest Conservation Network (MJUMITA) are coordinating in several villages in Tanzania (referred to in this paper as the TFCG/MJUMITA REDD+ pilot) with payments made to the village as a group. We focus particularly on: village-level decisions over how REDD+ funds are allocated within a village; the extent to which implementation of the REDD+ scheme accounts for group versus individual decisions; and whether the allocation of funds is linked to pressures on the REDD+ forest. We find that, though the pilot has taken into account monitoring, reporting and verification (MRV), and equity considerations, frequently no clear mechanism is articulated to ensure individual compliance with the village-level PES commitment nor to protect the village-level scheme from outsiders. In particular, villages allocate only very small shares of the REDD+ payments to formal enforcement efforts. While local institutions may be sufficient to ensure adherence to the REDD+ conditionality, a lack of more formalized enforcement could, however, prove problematic where outsiders with no connection to the REDD+ villages exert considerable external pressures on the forest.

The PES literature has been dominated by analyses of voluntary arrangements in which individual or coordinated landowners offer an ecosystem service in exchange for a payment. As such, PES can be considered to have its theoretical basis within a Coasean framework. Market or quasi-market bargaining can achieve socially optimal levels of environmental services [8] without additional government involvement beyond ensuring that property rights are well defined and protected. With relatively low transactions costs, if the ecological benefits are sufficient to warrant a large enough payment to a landowner to supply the ecosystem service rather than undertake alternate activities that are privately profitable but socially less desirable, then a PES is viable. Because the payment is contingent on a particular set of actions, the landowner has an incentive to comply without any external enforcement.

Operating from this basis of payments to induce changes in forest use behavior, early discussions of REDD+ as a new PES in the policy and academic literature focused on implementation issues including monitoring, reporting and verification (MRV); permanence; additionality; and leakage, for example [5,9-13]. However, increasingly PES schemes in lower-income countries are recognized to be more complex than the theoretical concept might suggest [14]. For example, there is explicit recognition that "community-based PES schemes offer a particular challenge, as incentives aimed to influence individual behavior ... pass through community institutions" [7] (p. 1263). A small number of papers consider lessons from PES schemes that are implemented partially or fully at a group rather than individual level [6] or on communal lands $[15,16]$. Indeed, many PES schemes stray far from the Coasean "ideal" of a "voluntary transaction where a well-defined ecosystem is bought by a buyer from a service provider if and only if the provider secures its provision" [8] (p. 1203), quoted from [17].

In these cases, conditionality operates through incentives at the group level but requires compliance at the individual level. Mechanisms to achieve such individual compliance include defining rules of resource access, rules of management actions per person, and consequences to breaking those rules. The development and enforcement of these allocation rules is critical-without established and enforceable rules, individual incentives from de facto open access remain even if individuals receive additional income from the project [18]. Yet the reality is that complex social-ecological systems (SESs) often lack a common framework to assess the likelihood of self-organization resulting in sustainable SESs [19]. 
Despite recognition that individual compliance with group decisions is difficult but necessary, the literature contains little consideration of how appropriate individual incentives are designed within a PES implemented at the group level. Two articles that address PES schemes in Mexico's common land, ejidos, discuss tree-stealing as a symptom of poorly enforced ejido property rights and the costs of that enforcement, but do not focus on ejido group decisions or incentives $[15,16]$. A case study from Madagascar explicitly recognizes this need within a PES context, yet pays relatively little attention to this issue in its specific study [7]. Rather, the results focus on how individuals within the defined group benefit differentially from the PES payment and on equity of the distribution of payments. Thus, although the economics and policy literatures recognize the prevalence of renewable resources managed at the group level in lower-income countries, analysis of the implications of individual decisions in response to PES payments to a group remain limited.

The paper is structured as follows. In Section 2 we provide details of the study site, our data collection, and our methodological approach. Section 3 sets out our findings. Finally, in Section 4 we consider the more general implications of our findings. This paper is relevant not only to REDD+ but to other forms of payments for environmental services (PES) and to general payment-as-compensation policies, particularly in lower-income countries, where payments are made at the group level and the group determines how these payments are allocated amongst individuals and group-level projects.

\section{Materials and Methods}

TFCG/MJUMITA introduced the project "Making REDD+ work for communities and forest conservation in Tanzania" in September 2009. The project's underlying philosophy incorporates the idea that forests are better managed when nearby communities are involved in the management of the forests, and that benefits should go directly to the village communities that are managing the forests. Documentation states that the project is implemented so as to "provide direct and equitable incentives to communities to conserve and manage forests sustainably" [20] (p. 1).

The project is being implemented in two districts in Tanzania-Kilosa and Lindi (Figure 1)—each of which incorporates biodiversity hotspots: the Eastern Afromontane biodiversity hotspot; and the Eastern African coastal forest biodiversity hotspot, respectively [21,22]. Though the pilot is being funded by a grant, it is being introduced as if it were a performance-based village-level PES in which village legal entities are paid proportionate to measurable and verifiable reductions in carbon emissions from specific forests within the village boundaries. Part of the rationale for this approach is that villages should therefore be well placed in the future to access REDD+ funds directly from international carbon markets.

TFCG/MJUMITA developed several norms as conditions for inclusion of a village in the pilot, where the village—or kijiji—is a nationally recognized level of administration [22]. First, the REDD+ payment is made to the village through the village natural resource committee (VNRC). Each VNRC must pass its own bylaws as to how the REDD+ "dividend" is allocated among three areas: community projects; individual village member dividends; and payments to the VNRC for enforcement/protection projects. Payments to individual village members can be influenced by, for example, the length of residency, age, and number of children in the household. However, the payment cannot be influenced by the cost imposed on an individual due to the REDD+ contract or the efforts that the individual makes towards achieving the REDD+ sequestration target [23].

To describe potential gaps between group and individual incentives in this pilot, our methodology involved: selecting villages; conducting stakeholder interviews in each village to collect management data and perception data; compiling a database from each village's management plans and records concerning payment dispersal; augmenting that database with stakeholder interview data; and assessing the resulting data to form a description of the range of responses to the village-level REDD+ payment scheme. First, rather than random sampling to determine which villages to include in our data collection and analyses, we selected all 21 pilot villages that had dispersed their initial REDD+ payments through a village-defined payment sharing mechanism at the time of data collection 
in 2013 and 2014. Second, a research team from the University of Dar es Salaam visited each village and conducted semi-structured interviews with the local TFCG/MJUMITA representative and members of the Village Natural Resource Committee (VNRC), including questions about their perceptions of the different pressures on the forests and the strengths of these pressures, using a Likert scale. We relied on these key stakeholder perceptions because there are no documented quantifiable data concerning the drivers of deforestation in each village. Third, the research team collected villageand project-level documentation concerning the REDD+ project and information on the different income-generating opportunities available to villagers. Project documents provided data detailing the total village REDD+ payment and the allocation of these funds across village-level projects, payments to individuals, and enforcement spending. We then constructed a database containing information from the interviews and the documentation. Last, we use economic concepts to examine these data, generating information about village-level decisions, to inform our discussion over group-level PES payments.

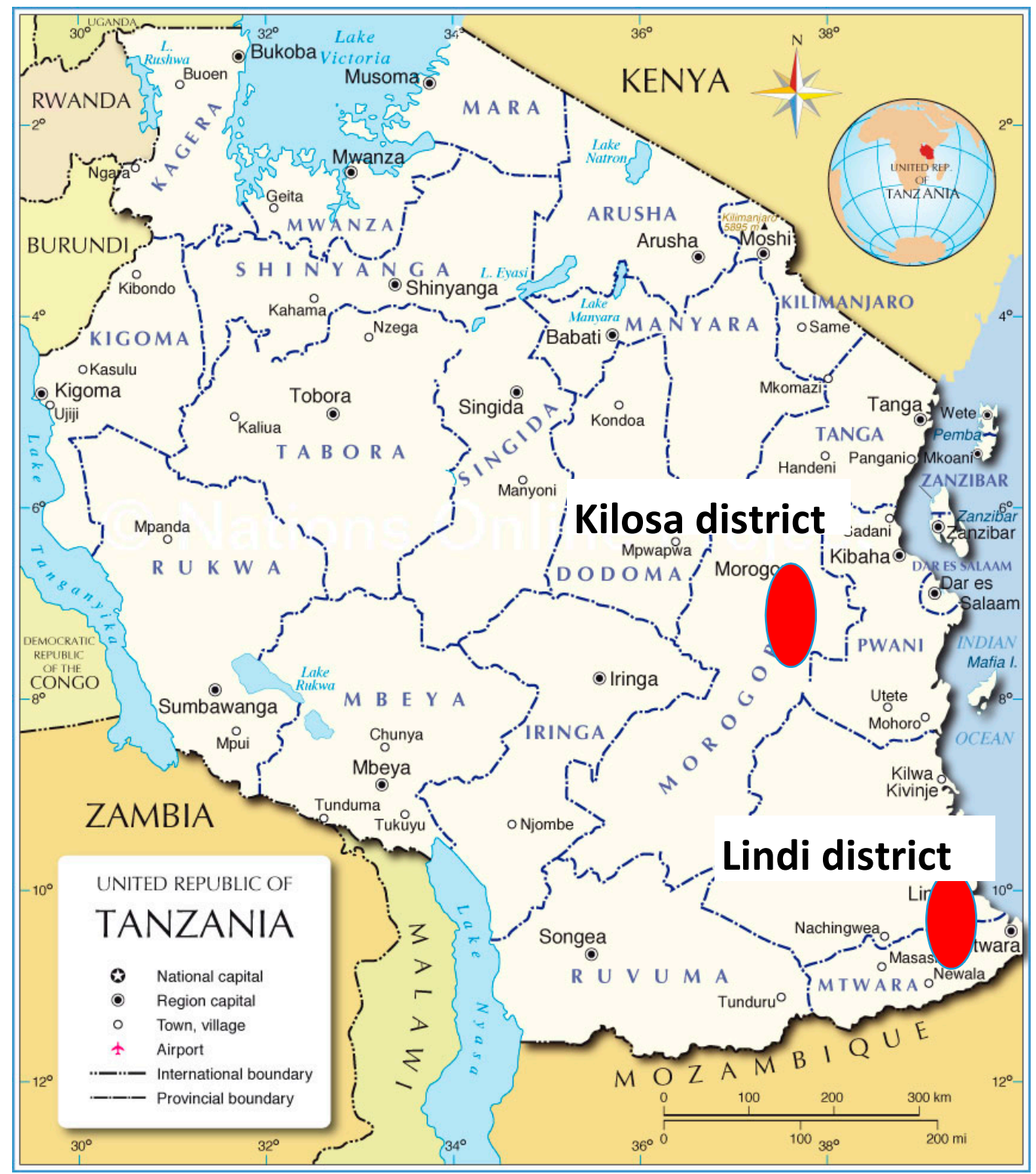

Figure 1. Map showing areas where pilot Reduced Emissions from Deforestation and Forest Degradation (REDD+) forests are located. Source: Nations Online [24]. 


\section{Results}

In this section, we describe the allocation of REDD+ payments to different uses and groups within each village. After providing a summary of the key elements of the "village land use management plans" developed in each village as a central element of the REDD+ pilot, we consider the payment allocations through the lens of the economic theory of incentives that underlies the use of REDD+ payments, as per the discussion above.

\subsection{Village Land Use Management Plans}

Villages have undertaken a broad range of activities in order to reduce the rate of forest loss relative to historical baselines, as detailed in "village land use management plans." These actions typically involve institution-building, to define and strengthen village-level forest land tenure through the establishment and legalization of community-based management, which includes the demarcation of village boundaries. As part of the management plan, each village undertakes forest and forest carbon monitoring, including: participatory assessments ("carbon accounting"); verification and reporting ("carbon marketing"); and financial management, including determining contracting and benefit-sharing mechanisms ("carbon financing"), developing by-laws that govern the REDD+ payments, and establishing REDD+ committees that are responsible for distributing funds [22]. Defining the rights of those households in the pilot village to enforce access restrictions against outsider households, and to limit extraction by members of the village, is an important element of the management plans. Local-level REDD+ readiness efforts include village land use planning and management activities to directly address the drivers of deforestation and forest degradation, and prevent leakage. These might variously restrict the extraction of timber and non-timber forest resources, and charcoal production. Some key initiatives include the promotion of conservation agriculture to reduce the incidence of shifting cultivation.

At the local level, the project as a whole went through a thorough process of ensuring free, prior and informed consent (FPIC), itself a requirement for Climate Community Biodiversity Alliance (CCBA) validation. This process took longer than expected and many useful lessons were learned, but it did have the effect of ensuring that only those activities that were acceptable and relevant to local communities were implemented. Consultations on village forest and land use management plans were extended down to the sub-village level to foster participation of poorer households living in more remote areas.

\subsection{REDD+ Payments and Allocations}

The size of the payment to each village is based on detailed estimates of historical rates, actual rates of deforestation with REDD+, and predicted future rates without REDD+ [23]. Thus, at the village level, efforts have been made to ensure a clear link between the payment and the reduction in forest loss. Across the 21 villages, these payments varied from Tsh $4.8 \mathrm{~m}$ to Tsh $63.2 \mathrm{~m}$ (in Tanzania shillings; US\$3,000-US\$39,500) at the village level, and from under US\$10 to over US\$100 at the per household per village level (Figure 2). Details of how these payments were determined, measured deforestation rates, and the monitoring, reporting, and verification, can be found in the relevant project details [20,22]. At the group level, the link between carbon payments and performance has provided a clear incentive for reduced deforestation in the project area. Payments are entirely determined by performance and no other criteria are used (such as social or poverty weightings). This has raised awareness locally on the need and value of addressing deforestation that often occurs through uncontrolled clearance, even when payments have been small at the individual level. However, there is no such link at the individual level for two key reasons. First, although households are likely to be affected differentially by the REDD+ pilot, paying equal individual dividends is a pragmatic approach to dealing with a situation in which much of the use of the forest before the implementation of REDD+ was de jure illegal. Second, all villagers have a similar monetary stake in protecting the forest in the future [23]. This approach 
focuses all stakeholders on a shared future rather than an imperfect past of de jure government forest rights that were rarely enforced with decades of technically illegal forest use by villagers.

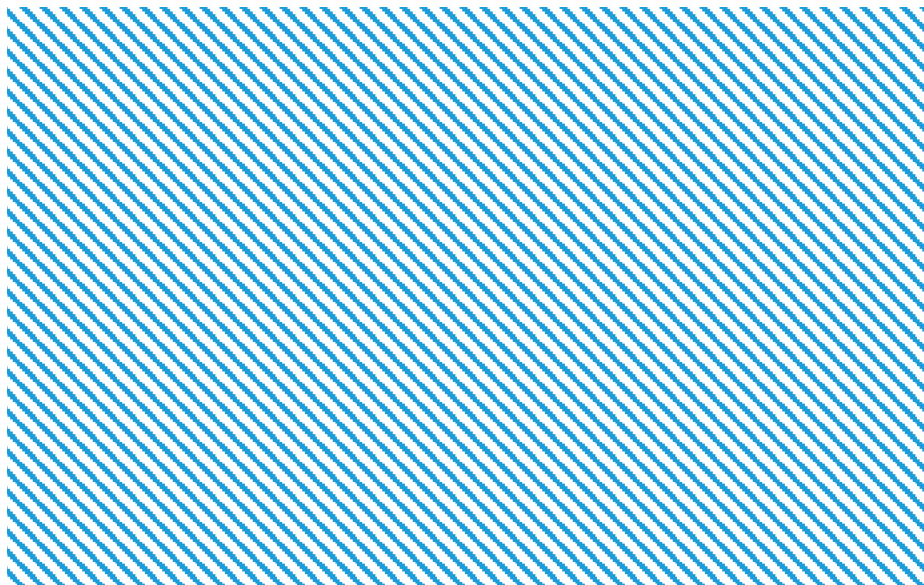

Figure 2. Level of payments per household by village.

We find a full range of sharing allocations between village-level projects and individual payments (Figure 3). However, across all villages, the allocation of funds for enforcement activities is small and, in many cases, zero. Whilst some villages allocated all the REDD+ payment to community projects, others allocated all or most of the payment as cash payments to individuals. Two villages allocated no cash to individuals but instead used the payment primarily for community projects, with a very small amount allocated to enforcement. On average, villages chose to allocate more of the REDD+ funds to individuals than to village-level projects. Given the widespread use of village-level projects as compensation for lost access to resources in national parks, marine parks, and conservation areas, this tendency to prefer payments to individuals over projects has broader implications for policy in Tanzania.

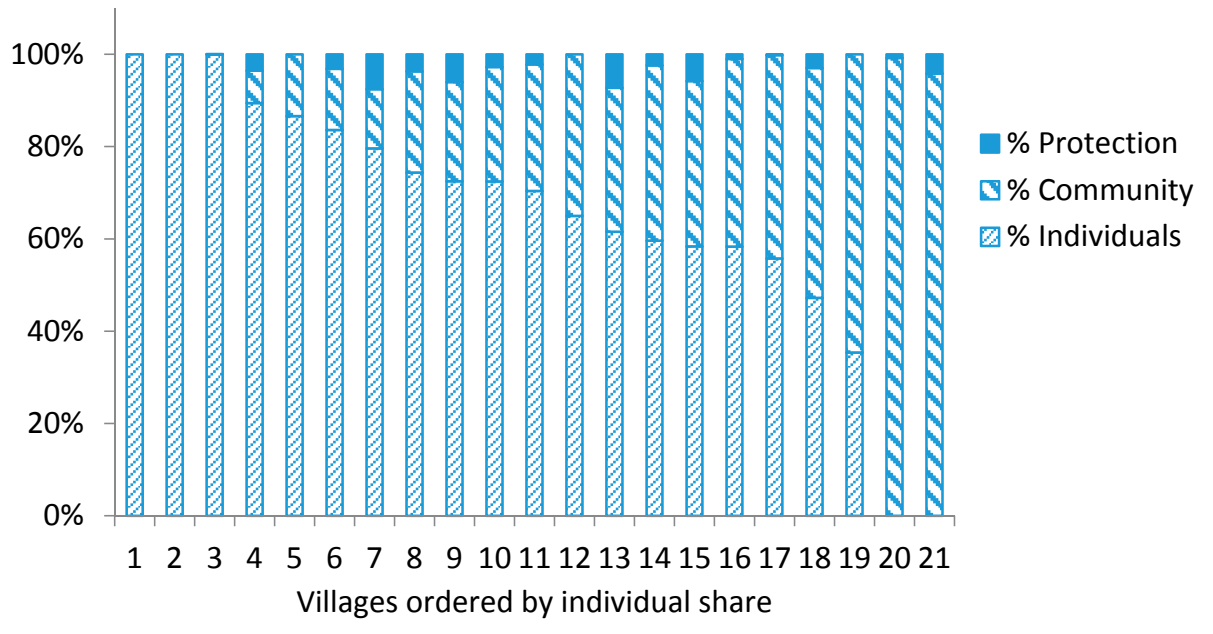

Figure 3. REDD+ funds allocated to individuals and group.

Villages that allocate funds towards village-level projects are eligible for matching funds from the local district. This added funding suggests a strong incentive for allocating at least some of the REDD+ funds towards such public good projects. However, whilst two villages did not allocate any of the REDD+ fund for individual payments, three villages did not allocate any REDD+ funds towards village-level projects. Discussions with village groups suggested two primary motivations for these allocation decisions. The first explanation for the allocation arises from the villages' 
perceived needs-some villages already have key community facilities such as a school, clinic, well, and public latrines, whereas others do not, which decreases the marginal value of village-level projects relative to individual payments. Second, one village stated that earlier bad experiences with poor management of community funds made them wary of entrusting funds to village committees and led to a preference for individual payments. In general, the question of the legitimacy of the VEC has been found to be important with respect to the success of community-based forest management in Tanzania [25]. However, for this particular REDD+ pilot, specific support actions were undertaken to increase institutional legitimacy, through strengthening and empowering the communities and village authorities in natural resource management. This is in line with the Village Land Act (1999), the Forest Act (2002), and the Local Government Act (1982), which provide the opportunity for village governments to have authority and the opportunity to generate revenue from sustainable management of their own natural resources. Through the establishment of village land forest reserves and local bylaws, village governments have been empowered to manage as well as benefit from forest management. Overall, in general, no clear pattern of allocations in this first year of the REDD+ pilot emerges (Figure 4).

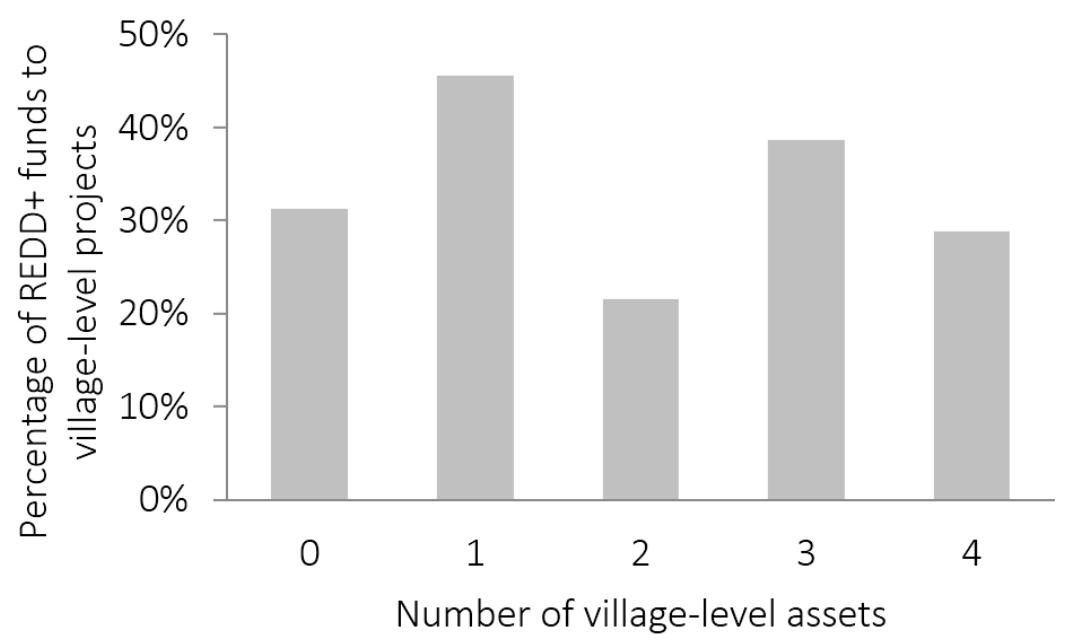

Figure 4. Link between community facilities before REDD+, and share of REDD+ payment.

\subsection{Enforcement and Links to Pressures on the Forests}

However the funds are allocated, when REDD+ is implemented at the group level, a mechanism is needed to ensure that individual villagers comply with the restrictions in order for the conditionality to be met. Explicit enforcement, which can be measured, primarily relies on patrols and punishments for those caught undertaking illegal activities within the REDD+ forest. Yet most of the villages do not allocate any funds to this type of protection (Figure 3).

One explanation for this lack of enforcement funding is that there has been considerable effort within these villages to build institutions. Experience with such institutions may reflect a tacit assumption that "social fencing" - a sense of collective responsibility to protect a commonly held and used resource-is sufficient to protect the REDD+ forests [23,26-30]. Social fencing may ensure compliance by influencing "insiders" to adhere to village-level regulations [23]. However, outsiders who are not part of the village and do not share in any REDD+ payment are unlikely to be subject to such pressures as they do not have a stake in the REDD+ forest and thus are not affected by REDD+ payments or a shared sense of future.

To explore the anthropogenic pressures leading to deforestation and forest degradation, and whether the key pressures came from insiders or outsiders, we interviewed groups of local individuals, comprised of male and female members of the village environmental committees and local representatives of TFCG. Although the data represent perceptions rather than measurable pressures, these village representatives expressed confidence in their understanding of the pressures that the 
local forests face. The stakeholders identified agricultural expansion, shifting cultivation, timber and charcoal production, and non-timber forest extraction as primary stressors on forests, and stated that both village members and outsiders contribute to this degradation. On average across villages, insider pressures are perceived to be greater than outsider pressures, mainly because shifting cultivation and farm expansion is only an option for villagers and not outsiders, by virtue of their location. However, both villagers and outsiders are perceived to cause both deforestation and degradation due to timber production and, to a lesser extent, charcoal production (Figure 5).

Greater perceived external pressure on the forest might reasonably imply a greater need for formalized enforcement activities and, therefore, a greater share of REDD+ funds allocated towards protecting the forest to increase the likelihood of the REDD+ payment being made, in accordance with a PES structure. In our data, however, we find no such relationship, whether with respect to perceived pressure on the forests from the village members themselves, or from outsiders using the forest for timber and charcoal production (Figure 6 presents the data for external pressures). This lack of a relationship contradicts our prior expectation.

Several possible explanations arise as to why villagers allocate so little of the REDD+ payment to managing and enforcing extraction restrictions in the REDD+ forest, even when there are outsider pressures. In many villages, patrols to protect the forest are voluntary, undertaken by village environmental committee members, and with no payments given or expected. This lack of direct payment does not, however, mean that the patrollers do not get remunerated. In the literature, there are examples of patrollers taking an informal payment when they catch someone undertaking illegal activities and thus receiving a reward for their actions, even though this financial transaction does not figure in any record keeping [31]. Some villages reported that they use fine revenues from village patrols to fund various protection activities, including making payments to the village account: five are using the funds to strengthen security; and one village uses the funds to contribute to village development. Thus, though fine revenue can be used in lieu of allocating REDD+ funds directly to enforcement, there is little evidence of a consistent source of funding for enforcement across the spectrum of villages. Further, using fines as a revenue source implies that both highly effective and highly ineffective enforcement result in low or no fine revenue [31].

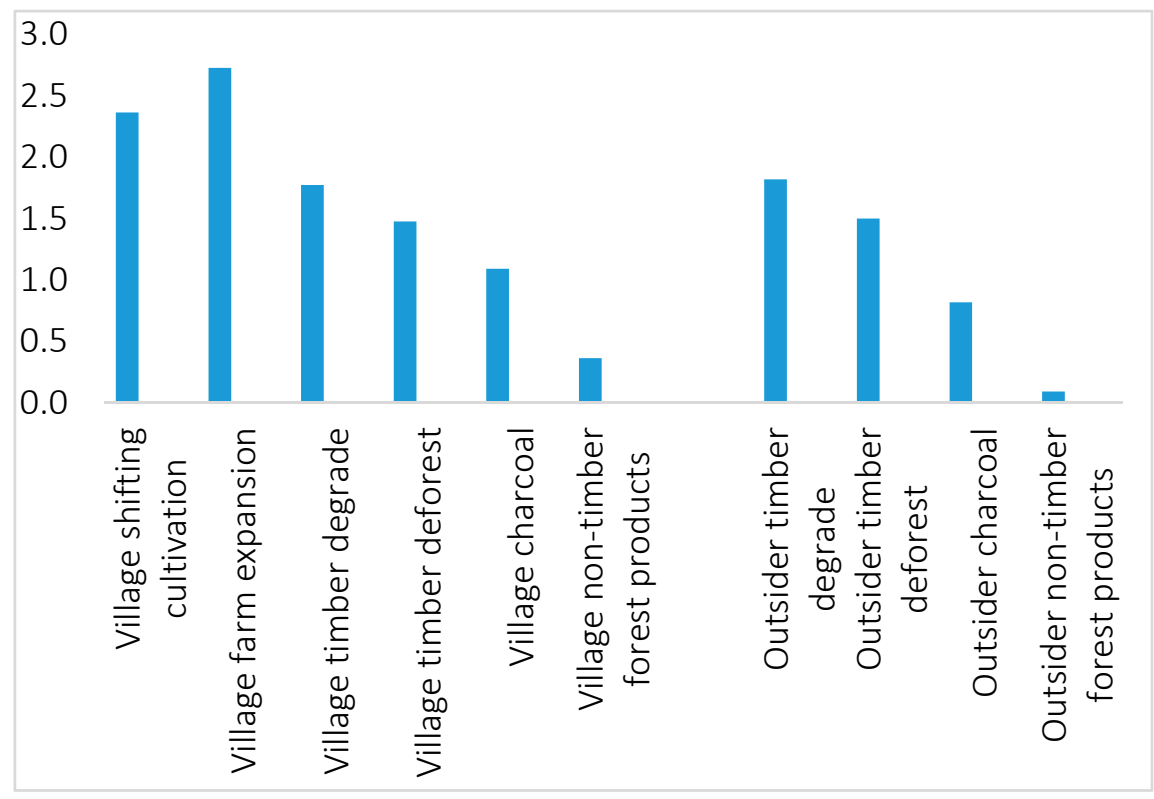

Figure 5. Perceived intensity of different drivers of forest loss. $(0=$ no perceived pressure; $3=$ high level of perceived pressure), averaged across all REDD+ (Reduced Emissions from Deforestation and Forest Degradation) villages. 


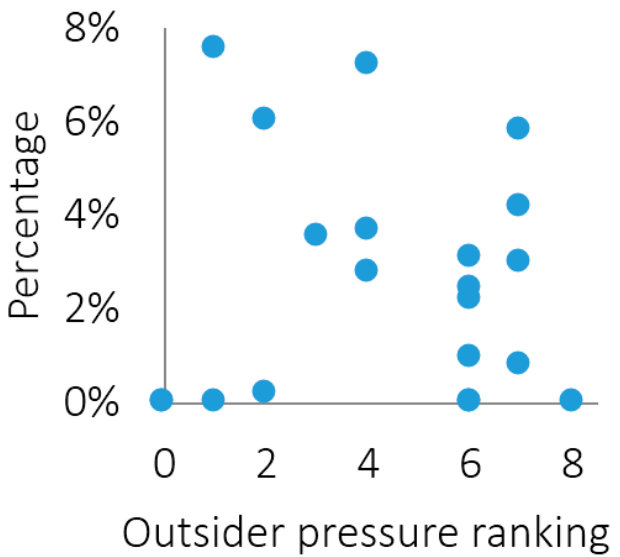

(a)

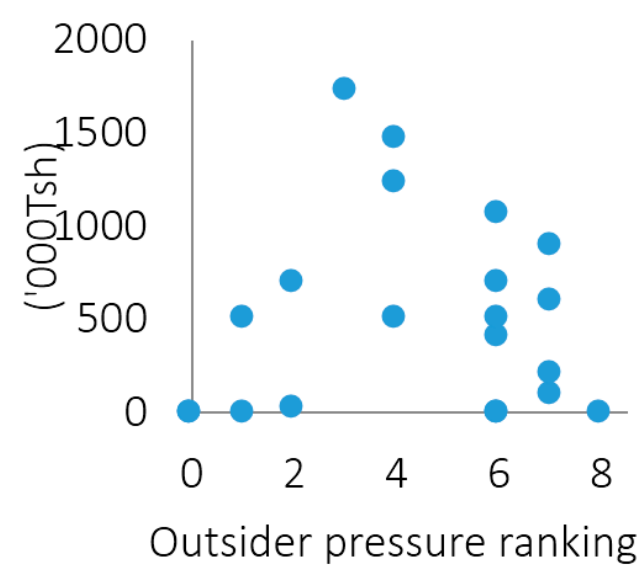

(b)

Figure 6. REDD+ enforcement spending: (a) Percentage of total REDD+ funds; (b) Tanzania shillings.

Alternatively, villagers may assume they can rely on social fencing alone to reduce the local use of the forest cooperatively, under-estimating the impact of external pressures on their ability to achieve the required REDD+ reduction. They may hesitate to enforce against outsiders due to: a sense of futility or impression of ineffective enforcement; inexperience with such interactions; concern for their legal standing; or fear of conflict. Lastly, villages may simply not perceive enforcement of the forest as an important element in the REDD+ agreement, especially given long-standing weak property rights institutions, and the possible belief that the payments will be made with or without a verified reduction in deforestation.

\subsection{Revenue Streams in the Short Term}

These REDD+ pilots have typically been introduced where on-going deforestation and degradation is a problem and thus there is scope for additionality. To achieve the goal of reduced forest loss, in the short run, villagers have been required to reduce or eliminate conversion of the REDD+ forest areas into other land uses, and to incur the set-up costs of a REDD+ PES scheme, before a verified reduction in forest loss has been achieved and thus before a truly conditional REDD+ payment can be made. Recognizing these upfront costs, and in common with other documented PES-type initiatives, the first REDD+ payments were made to the villages before any measured reduction in forest loss. The payments are seen as a way of increasing the likelihood that the village will cooperate with the REDD+ scheme in its early years of implementation. Other authors have also found such early payments to be a reality. For example, such "front loading" has occurred in one project in Uganda, in which the contracts ranged from 25 to 50 years but all the payments were dispersed by the tenth year of the project; and one in Mozambique in which the contract duration was 100 years but all the contracted payments were due to be paid out by the end of the seventh year [6]. Although these pre-payments may be criticized as negating the conditionality as in a true PES, without them such approaches to resource management could fail in the early years or not be accepted at the proposal stage, particularly in lower-income countries where households have few opportunities to smooth their consumption.

\section{Discussion}

With REDD+ pilots worldwide still new, little information details whether these payments lead to reduced carbon emissions from avoided forest loss. The specific Tanzanian pilot discussed here, however, allows an early examination of some of the REDD+ implementation issues that arise in the context of the program occurring where payments accrue to a group rather than creating individual incentives, and thus contributes to understanding on the potential of this and other group-level 
REDD+ programs to reduce forest loss and thus carbon emissions. Indeed, a large number of REDD+ programs are implemented at a group level on communally owned or managed forests, presenting a different situation than that envisaged in much of the REDD+ literature.

TFCG/MJUMITA's REDD+ pilots address institutional management issues by establishing or clarifying forest rights for a specific village and assisting with forest management planning, building on considerable experience of participatory forest management in the country. Our data suggest that there is considerable reliance on relationships within the villages to induce changes in the behavior of individuals within the village rather than using REDD+ payments to explicitly enforce forest management rules among members. For inclusion in these pilots, however, TFCG helps villages to define their legal rights to the forest and requires these villages to develop forest management institutions and plans. These activities may generate significant forest conservation even without the incentives from the payments themselves.

The interviewed villagers identified a number of external pressures on the forest that are perceived to be similar in strength to internal pressures, particularly timber and charcoal production. Yet there is little explicit enforcement spending to protect the forest from these outsider pressures. "Outsiders" who are not involved in the PES scheme have no incentive to comply with the REDD+ requirements, and so are likely to be deterred only through "fence and fine" approaches. We see examples of different approaches to influencing "insiders" and "outsiders" elsewhere. In Tanzania's Kibaha forest, villagers involved in the participatory forest management initiative have been encouraged to reduce the pressure on their forest in exchange for tree planting and beekeeping initiatives. Yet much of the pressure on this forest, located close to the main urban center of Dar es Salaam, comes from demand for charcoal in the city [23]. Villagers have found that enforcing their property right against outsiders is difficult even for experienced forest guards; village "insiders" are reluctant to engage in enforcement activities that lead to conflict and have limited legal standing within the forest. As the TFCG/MJUMITA REDD+ projects evolve over time, evidence should emerge as to the extent to which funds need to be explicitly allocated to enforcement activities.

These REDD+ pilots raise the question of what is a fair or equitable REDD+ scheme. Where private landowners are involved with PES, a key concern in lower-income countries is whether poorer households can access and thus be involved with the PES scheme [32-36]. In contrast, where the PES is implemented at a village level, a key equity concern is the differential impact on village members. In the REDD+ pilot discussed here, all households in the specific village are automatically included in the pilot and receive payments that are not linked to how an individual benefited from the forest before the REDD+ project. That rule aims at what might be considered forward-looking fairness, whilst accepting that inequities can remain because the costs imposed on each villager by changing forest behavior can differ markedly across villagers. Tying the equity issues to the functioning of the PES, the individual incentives to cooperate with the group's forest restrictions may be particularly low for villagers for whom there is a net cost to their participation in REDD+, even after the payment.

REDD+ is conceptually relatively straightforward: PES-type payments can be used to align private and social optima, so as to reduce the current rate of forest loss and thus carbon emissions. Yet in lower-income countries, where institutions governing forests are typically weak and often communal, and where people rely heavily on forests for their livelihoods, REDD+ implementation differs from that of a PES in a country with well-function property institutions. In the pilot here, the lack of pattern relating forest pressures to enforcement spending, and relating community public goods to the division of payments between community projects and individual payments, demonstrates that these payment schemes operate through complex social and institutional structures. For example, it is possible that uncertainties over future payments influence both group and individual behavior that complicates the classic interpretation of PES as creating conservation incentives based on conditionality.

In this project, organizing the initial payment was challenging because no performance had been achieved, but it was necessary to create incentives for future management. As such, the first round of payments was based on the villages' historical baseline and the percentage of the forest they decided 
to put into the village forest reserve. In hindsight, this may not have been a very effective means of predicting success. For example, in Nandambi, the village did not truly have control over all of the area put aside into the village land forest reserve, and this may have been a factor as to why the village failed to reach its initial targets. When the second payment was due (based entirely on actual performance against plans), Nandambi failed to reach their payment target again and some villagers felt somewhat disillusioned because this time the village did not receive any payments despite the efforts of the villagers. Reasons given for the relatively low levels of avoided forest loss include: on-going agricultural expansion; encroachment from neighboring villages; unregulated harvesting of forest products; and possible tension between the village natural resource committee and the village government. These findings present an important lesson regarding how one keeps communities interested, engaged and setting realistic targets until the first real "result" can be measured. Overall in Lindi district, two of the ten villages did not receive payments after the second year. Payments for the other villages varied between TSh3237 per villager and TSh91,377 per villager (between US\$2 and US\$55 in 2014), reflecting the varying extent to which villagers had verifiably reduced emissions relative to the counterfactual baseline, and the prevailing price of carbon.

Finally, the future and sustainability of REDD+ established by the project depends on the extent to which carbon finance can be secured through the voluntary market. The current international outlook is not promising, with prices at historically low levels. As such, the long-term sustainability of such REDD+ initiatives designed to reduce deforestation is uncertain.

Although the analysis in this paper cannot determine the underlying causes for the wide range of responses to the REDD+ pilot, the analysis signals that the implementation of REDD+ through group-level payments will require careful attention to the drivers of forest loss, balancing conditionality with the need to make some upfront payments to defer the initial costs imposed on households, and the individual incentives created within different village payment dispersal mechanisms to change forest use behavior and reduce emissions from forest use. This paper, in documenting one particular REDD+ pilot scheme, sheds light on some of the key issues for REDD+ implementation and other resource conservation strategies involving payments at a group level.

Acknowledgments: We gratefully acknowledge partial funding from the Sida-funded initiative, Environment for Development.

Author Contributions: Elizabeth Robinson and Jo Albers conceived the idea; Elizabeth Robinson wrote the first draft of the paper; Elizabeth Robinson, Jo Albers, Razack Lokina and Charles Meshack contributed to the methodological approach and data collection. Jo Albers, Razack Lokina and Charles Meshack contributed to the writing.

Conflicts of Interest: The authors declare no conflict of interest.

\section{References}

1. Van der Werf, G.R.; Morton, D.C.; De Fries, R.S.; Olivier, J.G.; Kasibhatla, P.S.; Jackson, R.B.; Collatz, G.J.; Randerson, J.T. $\mathrm{CO}_{2}$ emissions from forest loss. Nat. Geosci. 2009, 2, 737-738. [CrossRef]

2. Harris, N.L.; Brown, S.; Hagen, S.C.; Saatchi, S.S.; Petrova, S.; Salas, W.; Hansen, M.C.; Potapov, P.V.; Lotsch, A. Baseline map of carbon emissions from deforestation in tropical regions. Science 2012, 336, 1573-1576. [CrossRef] [PubMed]

3. Food and Agriculture Organization of the United Nations. Global Forest Resources Assessment 2005-Main Report FAO Forestry Paper No. 147; Food and Agriculture Organization of the United Nations: Rome, Italy, 2006.

4. Gibbs, H.K.; Brown, S.; Niles, J.O.; Foley, J.A. Monitoring and estimating tropical forest carbon stocks: Making REDD a reality. Environ. Res. Lett. 2007, 2. [CrossRef]

5. Albers, H.J.; Robinson, E.J.Z. Reducing emissions from deforestation and forest degradation. In Encyclopedia of Energy, Natural Resource, and Environmental Economics; Elsevier: Amsterdam, The Netherlands, 2013.

6. Mahanty, S.; Suich, H.; Tacconi, L. Access and benefits in payments for environmental services and implications for REDD+: Lessons from seven PES schemes. Land Use Policy 2013, 31, 38-47. [CrossRef] 
7. Sommerville, M.; Jones, J.P.; Rahajaharison, M.; Milner-Gulland, E.J. The role of fairness and benefit distribution in community-based Payment for Environmental Services interventions: A case study from Menabe, Madagascar. Ecol. Econ. 2010, 69, 1262-1271. [CrossRef]

8. Muradian, R.; Corbera, E.; Pascual, U.; Kosoy, N.; May, P.H. Reconciling theory and practice: An alternative conceptual framework for understanding payments for environmental services. Ecol. Econ. 2010, 69, 1202-1208. [CrossRef]

9. Angelsen, A. REDD models and baselines. Int. For. Rev. 2008, 10, 465-475. [CrossRef]

10. Humphreys, D. The politics of 'Avoided Deforestation': Historical context and contemporary issues. Int. For. Rev. 2008, 10, 433-442. [CrossRef]

11. Herold, M.; Skutsch, M.M. Measurement, Reporting and Verification for REDD; REDD: Medford, MA, USA, 2009.

12. Lubowski, R.N. What are the costs and potentials of REDD? In 2008 Moving AHEAD with REDD: Issues, Options and Implications; Angelsen, A., Ed.; CIFOR: Bogor, Indonesia, 2009.

13. West, S. Command without control: Are market mechanisms capable of delivering ecological integrity to REDD? Law Environ. Dev. J. 2010, 6, 298-319.

14. Tacconi, L. Redefining payments for environmental services. Ecol. Econ. 2012, 73, 29-36. [CrossRef]

15. Alix-Garcia, J.M.; de Janvry, A.; Sadoulet, E. Payments for Environmental Services: To Whom, for What, and How Much? In Proceedings of American Agricultural Economics Association Annual Meeting, Denver, CO, USA, 1-4 August 2016.

16. Alix-Garcia, J.M.; Shapiro, E.N.; Sims, K.R.E. Forest conservation and slippage: Evidence from Mexico's national payments for ecosystem services program. Land Econ. 2012, 88, 613-638. [CrossRef]

17. Engel, S.; Pagiola, S.; Wunder, S. Designing payments for environmental services in theory and practice: An overview of the issues. Ecol. Econ. 2008, 65, 663-674. [CrossRef]

18. Ostrom, E. Governing the Commons: The Evolution of Institutions for Collective Action; Cambridge University Press: Cambridge, UK, 1990.

19. Ostrom, E. A General Framework for Analyzing Sustainability of Social-Ecological Systems. Science 2009, 24, 419-422. [CrossRef] [PubMed]

20. Tanzania Forest Conservation Group. Making REDD Work for People and Forests in Tanzania: Lessons Learnt from Participatory Forest Management in Tanzania; Tanzania Forest Conservation Group: Dar es Salaam, Tanzania, 2009.

21. Robinson, E.J.Z.; Albers, H.J.; Meshack, C.; Lokina, R.B. Will REDD+ be successful in Tanzania? Practical issues of REDD+ implementation. In FOREST TENURE REFORM in Asia and Africa: Local Control for Improved Livelihoods, Forest Management, and Carbon Sequestration. Environment for Development; Bluffstone, R., Robinson, E.J.Z., Eds.; RFF Press: London, UK, 2014.

22. Dokken, T.; Putri, A.A.D.; Kweka, D. Making REDD work for communities and forest conservation in Tanzania. In REDD+ on the Ground: A Case Book of Subnational Initiatives across the Globe; Center for International Forestry Research (CIFOR): Bogor, Indonesia, 2014.

23. Robinson, E.J.; Albers, H.J.; Ngeleza, G.; Lokina, R.B. Insiders, outsiders, and the role of local enforcement in forest management: An example from Tanzania. Ecol. Econ. 2014, 107, 242-248. [CrossRef]

24. Nations Online. Available online: http://www.nationsonline.org/oneworld/first.shtml (accessed on 4 December 2016).

25. Rantala, S.; German, L.A. Exploring village governance processes behind community-based forest management: Legitimacy and coercion in the Usambara Mountains of Tanzania. Int. For. Rev. 2013, 15, 355-367. [CrossRef]

26. Mishra, P.R.; Sarin, M. Case Study 2 Social Security through Social Fencing, Sukhomajri and Nada North India. In The Greening of Aid: Sustainable Livelihoods in Practice; Earthscan Publications: London, UK, 1988.

27. Brandon, K.E.; Wells, M. Planning for people and wildlife: Design dilemmas. World Dev. 1992, 20, 557-570. [CrossRef]

28. Lal, J.B. Community forest management in Southern Asia: A survival issue. J. Sustain. For. 1997, 4, 73-88. [CrossRef]

29. Lise, W. Factors influencing people's participation in forest management in India. Ecol. Econ. 2000, 34, 379-392. [CrossRef] 
30. Henkemans, A.B. Tranquilidad and Hardship in the Forest: Livelihood and Perceptions of Camba Forest Dwellers in Northern Bolivian Amazon. Ph.D. Dissertation, University of Utrecht, Utrecht, The Netherlands, 2001.

31. Nielsen, M.R. Importance, cause and effect of bushmeat hunting in the Udzungwa Mountains, Tanzania: Implications for community based wildlife management. Biol. Conserv. 2006, 128, 509-516. [CrossRef]

32. Robinson, E.J.Z. Wanted dead and alive: To what extent are hunting and protection of an endangered species compatible? Environ. Dev. Econ. 2008, 13, 607-620. [CrossRef]

33. Kaimowitz, D. The prospects for reduced emissions from deforestation and degradation (REDD) in Mesoamerica. Int. For. Rev. 2008, 10, 485-495. [CrossRef]

34. Lambin, E.F. Monitoring forest degradation in tropical regions by remote sensing: Some methodological issues. Glob. Ecol. Biogeogr. 1999, 8, 191-198. [CrossRef]

35. Börner, J.; Wunder, S.; Wertz-Kanounnikoff, S.; Tito, M.R.; Pereira, L.; Nascimento, N. Direct conservation payments in the Brazilian Amazon: Scope and equity implications. Ecol. Econ. 2010, 69, 1272-1282. [CrossRef]

36. Blom, B.; Sunderland, T.; Murdiyarso, D. Getting REDD to work locally: Lessons learned from integrated conservation and development projects. Environ. Sci. Policy 2010, 13, 164-172. [CrossRef]

(C) 2016 by the authors; licensee MDPI, Basel, Switzerland. This article is an open access article distributed under the terms and conditions of the Creative Commons Attribution (CC-BY) license (http://creativecommons.org/licenses/by/4.0/). 